\title{
Analysis on Photovoltaic Energy-Assisted Drying of Green Peas
}

\author{
Onur Taşkın, Nazmi İzli, and Ali Vardar \\ Department of Biosystems Engineering, Faculty of Agriculture, Uludag University, 16059 Bursa, Turkey \\ Correspondence should be addressed to Onur Taşkın; onurtaskins@gmail.com
}

Received 18 August 2016; Revised 23 October 2016; Accepted 10 November 2016

Academic Editor: Ke Ma

Copyright (C) 2016 Onur Taşkın et al. This is an open access article distributed under the Creative Commons Attribution License, which permits unrestricted use, distribution, and reproduction in any medium, provided the original work is properly cited.

\begin{abstract}
A photovoltaic energy-assisted industrial dryer has been analyzed. The dryer has been tested in various weather and working conditions with $3 \mathrm{~kg}$ of green peas from $75.6 \%$ initial moisture content to $20 \%$ final moisture content (w.b.). The effect of various drying air temperatures at three levels $\left(40,50\right.$, and $\left.60^{\circ} \mathrm{C}\right)$ and two distinct air velocities $(3 \mathrm{~m} / \mathrm{s}$ and $4 \mathrm{~m} / \mathrm{s})$ was examined. Drying performance was assessed with regard to criteria including drying kinetics, specific and total energy consumption, and color and rehydration ratio. The results have proved that total drying duration reduces as air velocity rate and drying air temperature raise. Relying upon the drying durations, the generation performances of photovoltaic panels were between 5.261 and 3.953 W. On the other part, energy consumptions of dryer were between 37.417 and $28.111 \mathrm{~W}$. The best specific energy consumption was detected in $50^{\circ} \mathrm{C}$ at $3 \mathrm{~m} / \mathrm{s}$ for 600 minutes with $7.616 \mathrm{kWh} / \mathrm{kg}$. All drying conditions caused darkening as color parameters. Rehydration assays have showed that rehydrated green peas attained higher capacity with raised air temperature and air velocity.
\end{abstract}

\section{Introduction}

Green peas (Pisum sativum) are one of the most common and popular legumes in the world [1]. According to statistics prepared by Food and Agriculture Organization, dry green pea production in 2014 was nearly 11.3 million tons worldwide [2]. It has been extensively used in the human diet for a long time since it is an excellent source of protein, vitamins, minerals, and other nutrients and also high in fiber and low in fat and finally contains no cholesterol as well [3]. Because of its high moisture content, drying is an alternative method to preserve pea. Dried peas have become popular as they provide the advantage of longer shelf life, palatability, and convenience during its transportation and handling [4]. Also, drying of peas enables effective and practical preservation so as to minimize the losses after harvest. Like other legumes, dried peas can be used in meals or soups. Similarly, it is used in some traditional meals in UK and North America [5]. They are generally dried in thin layer by using hot air for industrial purposes [1].

Since ancient times, sun drying is one of the simple and well-known techniques of lessening the moisture content of the agricultural products. With respect to its negligible cost and energy need, it is advantageous. Conversely, this process is disadvantageous in terms of its slow speed and labor requirement. During drying, products can be polluted by dirt, dust, animals, insects, and microbial contamination and also this method has no protection against environmental conditions such as rain or storm as well [5]. As a result, loss in food quality in the dried products may have negative effects on their economic worth and trade potential. To prevent decline in quality of materials, various types of drying methods have been built. Conventional dryers among them are proved to be uneconomic because of their high energy cost [6]. Consuming minimum energy at maximum drying efficiency is aimed at industrial drying. For this reason, solar drying is a suitable choice which both provides low cost drying and decreases pollution of fossil fuel usage. Solar drying technology is simple and easy to adopt to domestic sector [7]. So as to benefit from free and renewable energy resources, in recent years, there have been several dryer attempts to preserve agricultural products [8].

About photovoltaic (PV) assisted dryers, Adelajaa et al. [9] demonstrated the integration of a suction fan which is powered by a solar PV module. An experiment was conducted in June on vegetable (Hydrophyllum). The designed dryer has drying chamber temperature of $58^{\circ} \mathrm{C}$ which is in conformance with the optimum temperature for drying 

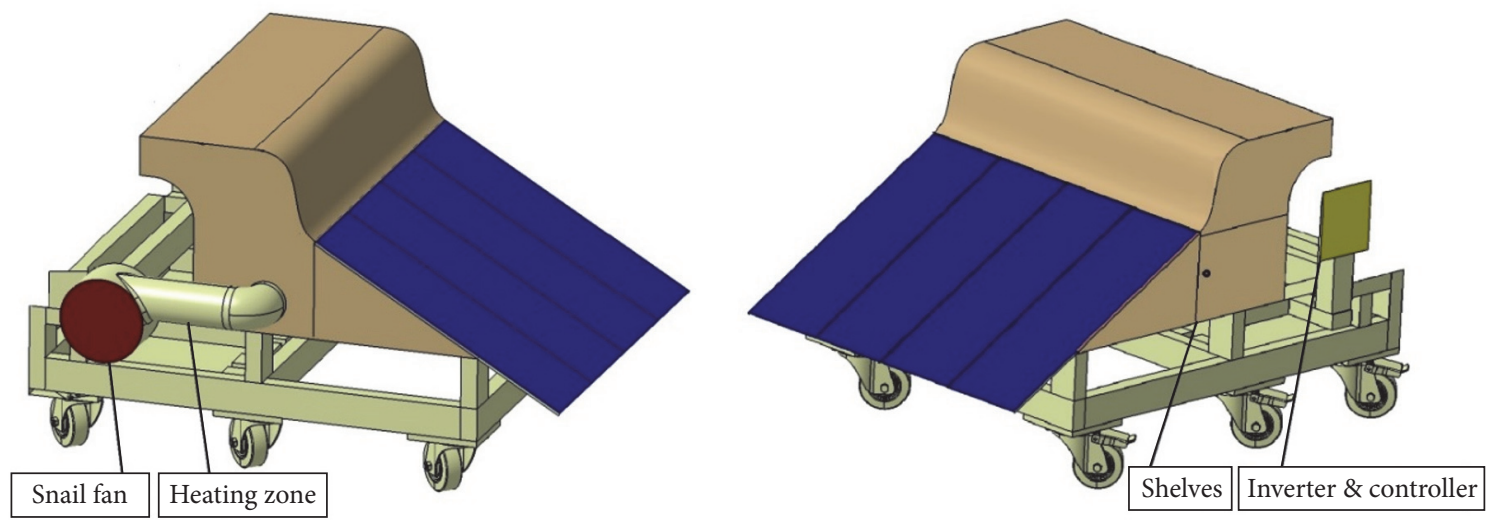

Figure 1: Technical drawing.

vegetables and its collector efficiency is $83.2 \%$. Nwosu et al. [10] depicted the design and experimental performance evaluation of a photovoltaic-powered solar drying system. The experimental outcomes indicate that, even at unfavorable weather conditions, the unit can produce cassava in good quality. Aktaş et al. [11] produced and analyzed the solar energy dryer that has $10 \mathrm{~kg}$ tomato capacity. Dryer has been used at various conditions. Required electricity and heat energy were provided by solar energy totally. Tomato slices were dried at drying air temperatures of $40^{\circ} \mathrm{C}, 45^{\circ} \mathrm{C}$, and $50^{\circ} \mathrm{C}$, respectively, and average $0.2 \mathrm{~m} / \mathrm{s}$ air velocity for 8.5 , 7 , and 6 hours, respectively. According to the results of the experiment average solar collector efficiency was calculated as $49.33 \%$. Ceylan et al. [6] also designed and produced a new type of solar dryer. In this experimental drying process tomatoes were used as well. The photovoltaic cells were used to run the fan and charge the batteries during the day as well. These charged batteries ran the halogen lamps during the night, and these halogen lamps were used to heat the dryingair-assisted photovoltaic cells. The solar dryer efficiency will increase in the summer season since solar radiation increases in this period. The dryer is called green solar dryer as the required power was supplied by using PV cells. Seveda [12] devised a photovoltaic-powered-forced convection solar dryer and assessed it in the conditions of $\mathrm{NEH}$ region of India. Dryer had a $6 \mathrm{~kg}$ capacity of chilies per batch. Average air temperature reached in the solar dryer was about $40^{\circ} \mathrm{C}$, which was higher than the ambient temperature. Chili drying process in a PV powered-forced convection solar dryer decreases the moisture content from nearly $80.2 \%$ (wet basis) to the final moisture content of nearly $10.0 \%$ in 32 hours.

In this research, the main objective is to assess the performance of the designed and manufactured PV-assisted dryer. Thin-layer green peas were used in the drying process in this experiment with the effects of various air temperature and air velocity on the drying time, color, rehydration ratio, and specific and total energy consumption.

\section{Materials and Methods}

Green peas (Pisum sativum), which were used in the drying experiments, were grown in the region of Yenişehir, Bursa,
Turkey. The product was harvested on June 29, 2016, and then was stored at $4.0 \pm 0.1^{\circ} \mathrm{C}$ to inhibit moisture loss. Before the drying experiments were conducted the harvest was carried out once and the same product was used during the all drying experiments. Uniform kernels which have average radius of $10.9 \pm 0.4 \mathrm{~mm}$ were used. Initial moisture contents of the samples were specified by oven drying (ED 115 Binder, Tuttlingen, Germany) at $105^{\circ} \mathrm{C}$ for 24 hours. Based on this initial moisture content analysis, moisture content was found to be $75.6 \%$, wet basis.

2.1. Experimental Setup. Developed dryer experiments had taken place under outdoor meteorological conditions of Field Laboratory of Department of Biosystems Engineering, Faculty of Agriculture, Bursa, Turkey $\left(40^{\circ} 13^{\prime} \mathrm{N}, 28^{\circ} 51^{\prime} \mathrm{E}\right)$. Technical drawing view of the dryer is exhibited in Figure 1.

This device contains $1 \mathrm{~kW}$ total capacity polycrystalline solar panel module (SFP250, Solarfield, Turkey) with horizontal angle of $30^{\circ}$ always facing south, $1.1 \mathrm{~kW}$ snail fan $(1.5$ 1500S, MTA, Turkey) that possesses digital potentiometer, $8 \mathrm{~kW}$ electric resistance heater zone, proportional integral derivative (PID) control processor with a PT100 thermocouple (Esm 7730, Emko, Turkey), twelve batteries (DC12V $100 \mathrm{~A}$ ) which are connected in series to get $48 \mathrm{~V}$ power source (SPG100/12, SB, China), inverter and controller, digital electric meters, and drying chamber that has four shelves $(198 \mathrm{~cm}-58 \mathrm{~cm})$. There was an $8 \mathrm{~cm}$ space between two trays. Only one tray was used in these experiments.

2.2. Test Procedure. In this research, the performance of PVassisted dryer was examined. The design had been performed by taking local conditions into account. The experiments were carried out between the dates July 01 and July 14, 2016, between the hours 10:00 am and 8:00 pm with duple replicate. The dryer was placed away from any shadow throughout the experiment. For thin-layer drying, samples were put on wire mesh trays.

In order to understand the effect of environmental conditions, average environmental data measurements in July were recorded by the datalogger (Cr1000, Campell Scientific, USA) for 12 days. The dataset is composed of $1 \mathrm{~min}$ averaged 
measurements of global horizontal irradiance (CM11 pyranometer, Kipp\&Zonen, Netherlands), direct normal irradiance (CHP1 pyrheliometer, Kipp\&Zonen, Netherlands) with an installed on solar tracker, sunshine duration (CSD 3 Sensor, Kipp\&Zonen, Netherlands), ambient temperature (41342, Young, USA), and ambient humidity (41003, Young, USA). The station is placed just besides the dryer.

\subsection{Analysis Procedure}

2.3.1. Drying Kinetics. By visually inspecting, damaged, immature, and dry pods were excluded manually. In addition the pea pods were shelled by hand [4]. After separation of green peas, it dried in dryer with air temperatures of 50, 60, and $70^{\circ} \mathrm{C}$ [13], respectively at $3 \mathrm{~m} / \mathrm{s}$ and $4 \mathrm{~m} / \mathrm{s}$ air velocities $[14,15]$. Single layers of drying were performed on a mesh tray which was containing fresh green peas of $3 \mathrm{~kg}$. Then digital grain moisture tester gauged the moisture content (Mini GAC plus, Dickey-John, USA) [16]. This procedure was repeated until moisture content was decreased to $20 \%$ (w.b.) [17]. After drying process, the product was cooled for 10 minutes and then it was kept in air glass jars for one week by the time color and rehydration measurements were carried out [18].

\subsubsection{Specific and Total Energy Consumption. Specific energy} consumption was defined as the energy required to remove a unit mass of water in drying process [19]. This specific energy calculation was expressed as $\mathrm{kWh} / \mathrm{kg}$ of the moisture removed. On the other hand, for air heating and blower running total energy consumption of dryer was calculated by using a digital electric counter (AEL MF 07, Kohler, Turkey) [20]. Moreover energy production realized by PV panels has been measured (Bk325, GT Power RC, China) during the drying period and it was excluded from total consumption.

2.3.3. Color. A colorimeter has determined the color of initial and dried samples (EZ 4500L, Hunter Lab, USA). Commission Internationale d'Eclairage was embraced with the three-dimensional color space and construed as follows: $L^{*}$ is the brightness value which ranges from no reflection for black $(L=0)$ value to perfect diffuse reflection for white $(L=100)$ value. $a^{*}$ value is the redness which ranges from negative values that represent green to positive values that represent red. $b^{*}$ value is the yellowness which ranges from negative values that stand for blue and positive values that stand for yellow [21]. Before the color measurement operations, calibration of the device was completed by utilizing a standard white plate ( $x=82.43, y=84.55$, and $z=99.39)$ and also utilizing a standard black plate $(x=0, y=0$, and $z=0$ ). In the course of the measurements, green peas were superposed in order to cover the surface of the black cylindrical box totally [22].

2.3.4. Rehydration. Rehydration experiments were conducted with dried samples of $10 \mathrm{~g}$ which were put into a cloth and placed in a beaker in which there is $250 \mathrm{~mL}$ distilled water. The beakers were retained at room temperature of

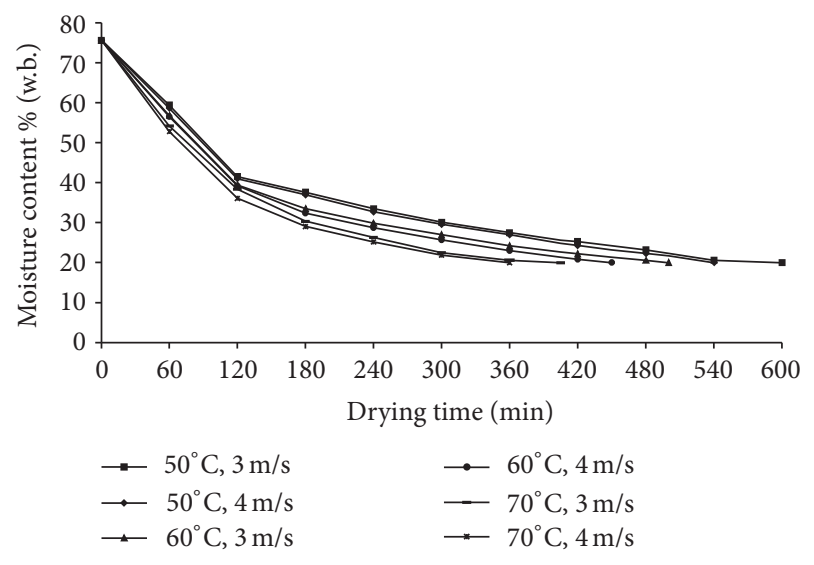

FIgURE 2: Air temperature and air velocity influence on green peas drying.

nearly $20^{\circ} \mathrm{C}$, for 14 hours time. Afterwards, these samples were taken out from the beaker and drained over a mesh so as to remove the superficial water, and then they were weighed by digital balance (PS 4500, Radwag, Poland). Rehydration capacity was identified as the ratio of the total weight of the sample to the dry weight of it after rehydration in grams [23].

2.4. Statistical Analysis. Obtained results were processed by using MS-Excel software. After examination of the each drying method, so as to assess any significant difference between the color and the rehydration capacity a one-way analysis of variance was used. All calculations were done by means of the JMP software (version 7.0, NC, USA). Unless otherwise specified, differences were regarded as significant at $P<0.05$ value.

\section{Results and Discussion}

For reduction of moisture content, effects of different drying air temperatures and air velocities are shown in Figure 2. Obtained results indicated that drying of green peas was performed at air temperatures of 50,60 , and $70^{\circ} \mathrm{C}$ at a constant drying air velocity of $3 \mathrm{~m} / \mathrm{s}$ and took about 600,500 , and 405 minutes, respectively. In addition to this, the drying of green peas continued about 540,450 , and 360 minutes in 50,60 , and $70^{\circ} \mathrm{C}$ at a constant drying air velocity of $4 \mathrm{~m} / \mathrm{s}$, respectively. The drying duration was reduced by 1.48 times in proportion to the drying process which was realized in 50 to $70^{\circ} \mathrm{C}$ at $3 \mathrm{~m} / \mathrm{s}$ air velocity. Likewise, drying duration was surged about 1.50 times, if the drying temperature reduced from 70 to $50^{\circ} \mathrm{C}$ at $4 \mathrm{~m} / \mathrm{s}$ air velocity. As a result, the drying duration is expected to reduce the moisture which was at the highest level in $50^{\circ} \mathrm{C}$ at $3 \mathrm{~m} / \mathrm{s}$ air velocity and at the lowest level in $70^{\circ} \mathrm{C}$ at $4 \mathrm{~m} / \mathrm{s}$ air velocity and consequently the average total drying duration decreased about $40 \%$ times. As it can be seen, higher drying temperatures and air velocities will improve the kinetic energy of water molecules, and ultimately it stimulates water evaporation rate. For this reason, drying duration reduced with increased air temperature and velocity. So these results are in line with the previous researches. 
Results about the increase in drying air temperatures are similar to those founded by Taechapairoj et al. [24] for paddy, Doymaz [25] for green bean, Rattanamechaiskul et al. [26] for purple rice, and Doymaz [27] for red kidney bean seeds. In other respects, it has been seen that the increase in air velocity has significantly reduced the drying duration at other researches such as Afzal et al. [28] for barley, Darvishi et al. [29] for soybean, and Chielle et al. [30] for papaya seeds.

The environmental conditions are depicted on Figure 3. Experiments were conducted in clear sunshine sky conditions and started at 10:00 am till the moisture content was reduced to $20 \%$. According to the average daily results gathered from the research shown in Figures 3(a)-3(f), it can be assumed that the ratio of global solar radiation intensity during the experiments was around $667.20 \mathrm{~W} / \mathrm{m}^{2}$ for $50^{\circ}$ and $3 \mathrm{~m} / \mathrm{s}, 723.25 \mathrm{~W} / \mathrm{m}^{2}$ for $50^{\circ}$ and $4 \mathrm{~m} / \mathrm{s}, 741.74 \mathrm{~W} / \mathrm{m}^{2}$ for $60^{\circ}$ and $3 \mathrm{~m} / \mathrm{s}, 798.30 \mathrm{~W} / \mathrm{m}^{2}$ for $60^{\circ}$ and $4 \mathrm{~m} / \mathrm{s}, 843.83 \mathrm{~W} / \mathrm{m}^{2}$ for $70^{\circ}$ and $3 \mathrm{~m} / \mathrm{s}$, and $874.25 \mathrm{~W} / \mathrm{m}^{2}$ for $70^{\circ}$ and $4 \mathrm{~m} / \mathrm{s}$; and the ratio of direct solar radiation intensity during the experiments was approximately $750.44 \mathrm{~W} / \mathrm{m}^{2}$ for $50^{\circ}$ and $3 \mathrm{~m} / \mathrm{s}, 771.48 \mathrm{~W} / \mathrm{m}^{2}$ for $50^{\circ}$ and $4 \mathrm{~m} / \mathrm{s}, 782.14 \mathrm{~W} / \mathrm{m}^{2}$ for $60^{\circ}$ and $3 \mathrm{~m} / \mathrm{s}, 815.55 \mathrm{~W} / \mathrm{m}^{2}$ for $60^{\circ}$ and $4 \mathrm{~m} / \mathrm{s}, 824.93 \mathrm{~W} / \mathrm{m}^{2}$ for $70^{\circ}$ and $3 \mathrm{~m} / \mathrm{s}$, and $843.10 \mathrm{~W} / \mathrm{m}^{2}$ for $70^{\circ}$ and $4 \mathrm{~m} / \mathrm{s}$; and the ambient temperature during the experiments is approximately $29.70^{\circ} \mathrm{C}$ for $50^{\circ}$ and $3 \mathrm{~m} / \mathrm{s}, 29.63^{\circ} \mathrm{C}$ for $50^{\circ}$ and $4 \mathrm{~m} / \mathrm{s}, 30.93^{\circ} \mathrm{C}$ for $60^{\circ}$ and $3 \mathrm{~m} / \mathrm{s}, 30.05^{\circ} \mathrm{C}$ for $60^{\circ}$ and $4 \mathrm{~m} / \mathrm{s}, 30.58^{\circ} \mathrm{C}$ for $70^{\circ}$ and $3 \mathrm{~m} / \mathrm{s}$, and $30.32^{\circ} \mathrm{C}$ for $70^{\circ}$ and $4 \mathrm{~m} / \mathrm{s}$; and the relative humidity during the experiments is approximately $46.87 \%$ for $50^{\circ}$ and $3 \mathrm{~m} / \mathrm{s}, 47.94 \%$ for $50^{\circ}$ and $4 \mathrm{~m} / \mathrm{s}, 43.54 \%$ for $60^{\circ}$ and $3 \mathrm{~m} / \mathrm{s}, 42.64 \%$ for $60^{\circ}$ and $4 \mathrm{~m} / \mathrm{s}$, $39.25 \%$ for $70^{\circ}$ and $3 \mathrm{~m} / \mathrm{s}$, and $35.93 \%$ for $70^{\circ}$ and $4 \mathrm{~m} / \mathrm{s}$. Within this framework, it was concluded that drying time and environmental conditions have influenced the total amount of electricity produced from solar panel.

For various drying treatments, energy consumption variation (electric resistances and blower) and energy production from PV are depicted in Figure 4. When comparison of the different drying processes with regard to energy consumption values was conducted, it was noticed that temperature rise of air that has relative humidity is significant for energy consumption of electric resistances. Additionally, if the heating unit works with low air temperature, the dryer requires less energy. Among all drying methods, the lowest and highest energy consumptions were seen at $50^{\circ} \mathrm{C}$ at $3 \mathrm{~m} / \mathrm{s}$ and $70^{\circ} \mathrm{C}$ at $4 \mathrm{~m} / \mathrm{s}$, respectively. During the drying durations, when the PV panels produced energy, the average total energy consumption decreased about $10.56 \%$ to $18.71 \%$.

The specific energy increased with increased air velocity (at constant temperature) as it can be seen at Figure 5. Data results display that, for green peas, the highest value of the specific energy was $11.154 \mathrm{~kW} \mathrm{~h} / \mathrm{kg}$ in $70^{\circ} \mathrm{C}$ at $4 \mathrm{~m} / \mathrm{s}$ and the lowest value of the specific energy was attained in $50^{\circ} \mathrm{C}$ at $3 \mathrm{~m} / \mathrm{s}$ to be $7.616 \mathrm{~kW} \mathrm{~h} / \mathrm{kg}$. So it means that choosing the proper temperature and air velocity leads to reduced specific energy consumption. In the literature similar results can be found such as Adabi et al. [31] who dried squash seeds in semifluidized and fluidized-bed dryers. Obtained results indicated that increase in air velocity leads to apparent increase in the value of specific energy consumption. Chayjan et al. [32] examined the specific energy consumption of several drying methods for black mulberry. From that research, it was understood that drying at higher air velocities ends in more energy consumption.

Summary of the average color values $\left(L^{*}, a^{*}\right.$, and $\left.b^{*}\right)$ of fresh and green peas which undergo various drying processes are seen at Table 1 . While the brightness values $\left(L^{*}\right)$ of fresh samples were 44.11 , the greenness/redness $\left(a^{*}\right)$ values were -5.49 and the yellowness/blueness $\left(b^{*}\right)$ values were 31.82 . These results indicate that all of the drying experiments have affected the color changes as expected. $L^{*}$ value which is most close to those of fresh green peas was obtained in $70^{\circ} \mathrm{C}$ at $4 \mathrm{~m} / \mathrm{s}$ air velocity, whereas the most remote $L^{*}$ value was obtained in $50^{\circ} \mathrm{C}$ at $3 \mathrm{~m} / \mathrm{s}$ air velocity. Furthermore, $L^{*}$ value diminishes on account of the long drying duration. As compared to fresh green peas, it was found that $a^{*}$ and $b^{*}$ values raised during drying significantly. While the air temperature and air velocity increased, the final $a^{*}$ values ranged from -0.15 to -2.51 . For this reason, green peas samples lost their greenness. It can be seen from Table 1 that $b^{*}$ value raised with decreased drying duration. It was mentioned that $b^{*}$ values of dried green peas reduced from 31.82 to 28.08 and 24.01 during various air temperatures and air velocities. Through the instrument of the statistical analysis, it was confirmed that both increase of the air temperature and increase of the air velocity have influenced the color values $(P<0.05)$ significantly. Similar color deviations were emphasized by some authors. Ben Haj Said et al. [33] asserted that the negative $a^{*}$ value of Allium roseum leaves increases significantly, after the application of thinlayer convective drying at three temperatures (40,50, and $60^{\circ} \mathrm{C}$ ) and two air velocities $(1.0$ and $1.5 \mathrm{~m} / \mathrm{s})$. Demiray and Tulek [34] examined the influence of temperature on color change kinetics of carrot slices. Finally, the color values were influenced by hot air drying; for instance, $L^{*}$ values decreased from 57.87 to 49.32 at $65^{\circ} \mathrm{C}$. Additionally, Aral and Beşe [35] applied the color analysis to thin-layer drying of hawthorn fruit (Crataegus spp.) at air temperatures of 50, 60, and $70^{\circ} \mathrm{C}$ and air velocities of $0.5,0.9$, and $1.3 \mathrm{~m} / \mathrm{s}$ in a convective dryer. They discovered that decrease of the drying air temperature and air velocity which led to longer drying time and decrease of $b^{*}$ value can be regarded as the yellowness that fruit loses.

Rehydration ratio characteristics of green peas which were dried at different temperatures and air velocities are depicted in Table 1. General results were observed as follows. The maximum rehydration capacity, which was 2.35 , was obtained in $70^{\circ} \mathrm{C}$ at $4 \mathrm{~m} / \mathrm{s}$. In the same way, the minimum rehydration capacity, which was 2.26 , was obtained in $50^{\circ} \mathrm{C}$ at $3 \mathrm{~m} / \mathrm{s}$. Taking the individual effects into account, the average rehydration capacity of samples raises with the increase of air temperature and velocity. In addition, the statistical analysis indicated that there was no significant difference between the rehydration capacity in $50^{\circ} \mathrm{C}$ at $3 \mathrm{~m} / \mathrm{s}$ and the rehydration capacity in $70^{\circ} \mathrm{C}$ at $4 \mathrm{~m} / \mathrm{s}$, at $5 \%$ probability level only. A behavior like this was reported in a few researches conducted about hot air drying of pumpkin slices [36], nata de coco [37], and Rosa rubiginosa fruits [38]. 


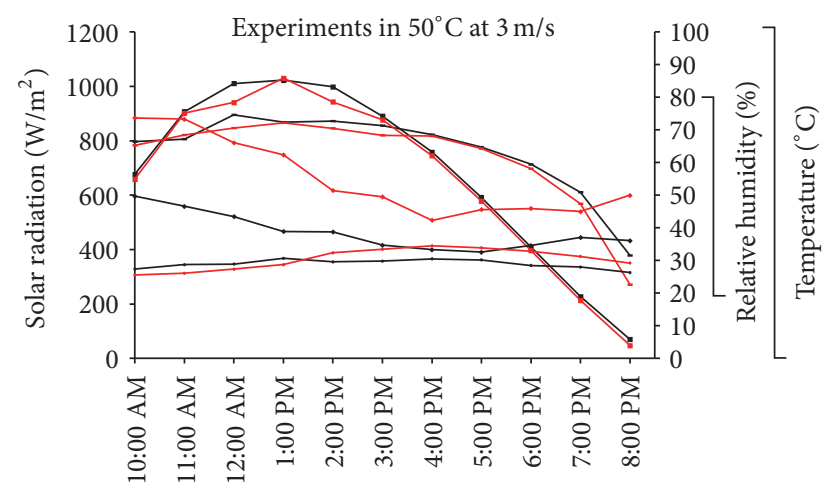

Local time of days (08.07.2016 and 14.07.2016)

- Global irradiance $1 \rightarrow$ Global irradiance 2

- Direct irradiance 1 Direct irradiance 2

$\rightarrow$ Ambient temperature $1 \div$ Ambient temperature 2

$\multimap$ Relative humidity $1 \multimap$ Relative humidity 2

(a)

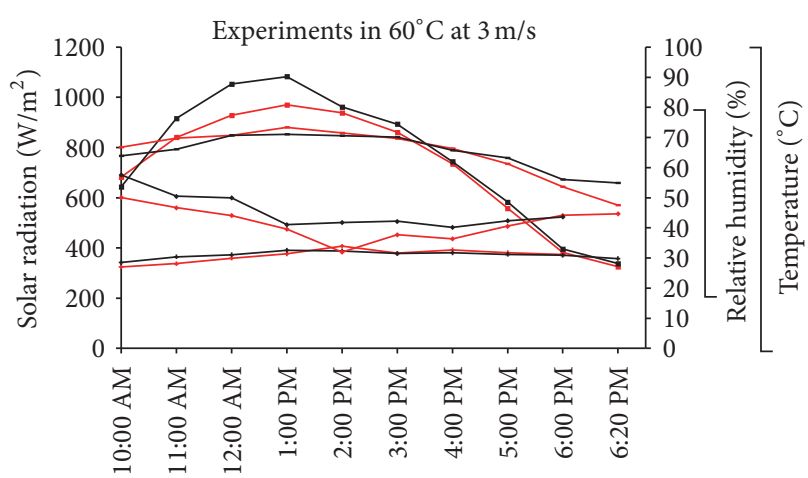

Local time of days (04.07.2016 and 12.07.2016)

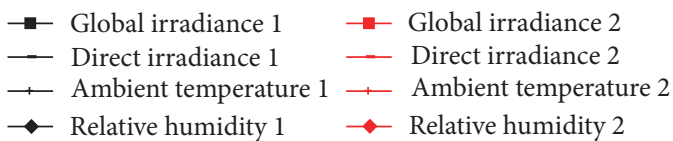

(c)

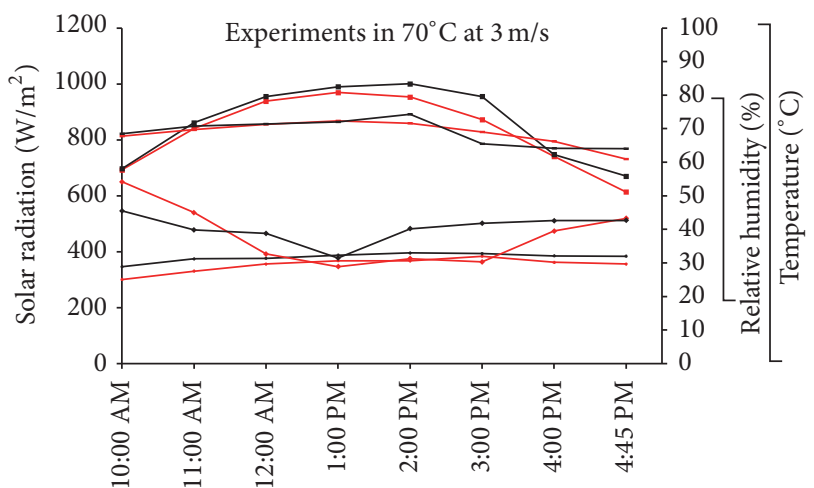

Local time of days (02.07.2016 and 10.07.2016)

$\rightarrow$ Global irradiance $1 \rightarrow$ Global irradiance 2

- Direct irradiance 1 Direct irradiance 2

- Ambient temperature $1 \multimap$ Ambient temperature 2

$\rightarrow$ Relative humidity $1 \rightarrow$ Relative humidity 2

(e)

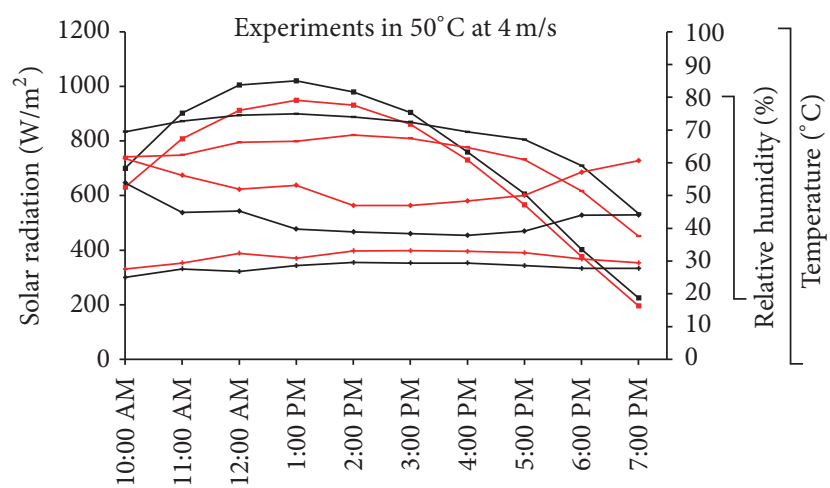

Local time of days (06.07.2016 and 13.07.2016)

- Global irradiance $1 \longrightarrow$ Global irradiance 2

- Direct irradiance 1 Direct irradiance 2

$\longrightarrow$ Ambient temperature $1-$ Ambient temperature 2

$\bullet$ Relative humidity $1 \multimap$ Relative humidity 2

(b)

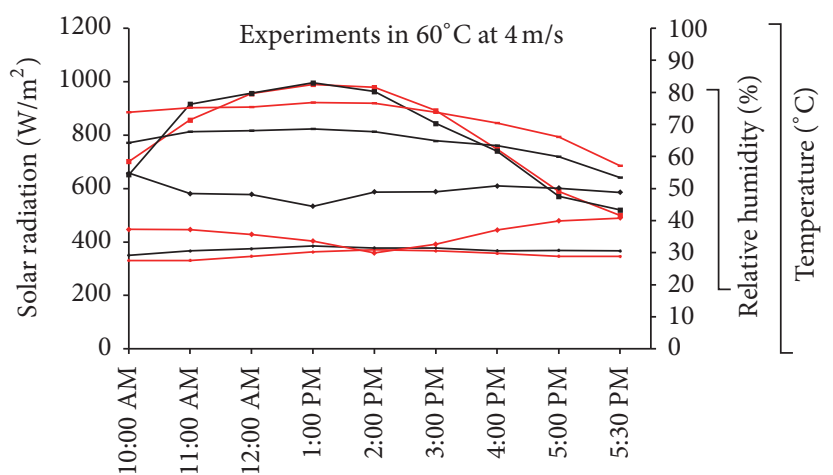

Local time of days (03.07.2016 and 11.07.2016)

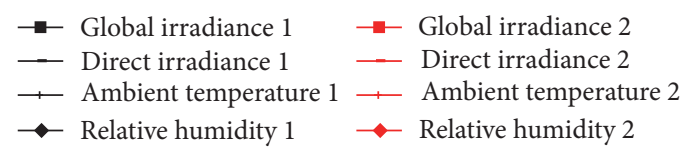

(d)

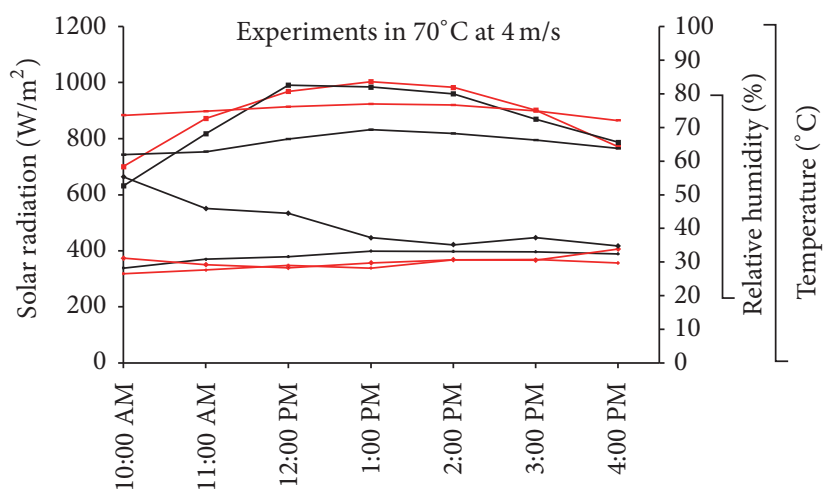

Local time of days (01.07.2016 and 09.07.2016)

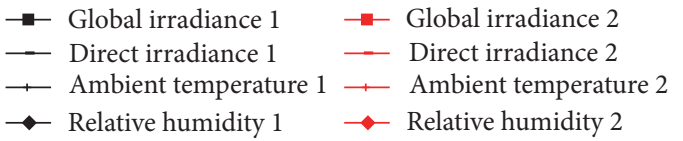

(f)

FIGURE 3: Climatic data of experimental dates (black and red lines are symbolize the 1st and 2nd dates, resp.). 
TABLE 1: Hunter $L^{*} a^{*} b^{*}$ values and rehydration ratio of green peas.

\begin{tabular}{lccccc}
\hline & & $L^{*}$ & $a^{*}$ & $b^{*}$ & Rehydration capacity \\
\hline Fresh & & $44.11 \pm 0.38^{\mathrm{a}}$ & $-5.69 \pm 0.02^{\mathrm{e}}$ & $31.82 \pm 0.23^{\mathrm{a}}$ & - \\
& $50^{\circ} \mathrm{C}$ & $34.64 \pm 1.10^{\mathrm{f}}$ & $-2.51 \pm 0.57^{\mathrm{d}}$ & $24.01 \pm 0.71^{\mathrm{f}}$ & $2.26 \pm 0.01^{\mathrm{a}}$ \\
$3 \mathrm{~m} / \mathrm{s}$ & $60^{\circ} \mathrm{C}$ & $36.96 \pm 0.93^{\mathrm{e}}$ & $-2.15 \pm 0.03^{\mathrm{c}}$ & $26.49 \pm 0.14^{\mathrm{d}}$ & $2.27 \pm 0.01^{\mathrm{a}}$ \\
& $70^{\circ} \mathrm{C}$ & $39.55 \pm 0.20^{\mathrm{d}}$ & $-0.46 \pm 0.12^{\mathrm{a}}$ & $27.36 \pm 0.53^{\mathrm{bc}}$ & $2.32 \pm 0.09^{\mathrm{a}}$ \\
& $50^{\circ} \mathrm{C}$ & $40.93 \pm 0.56^{\mathrm{c}}$ & $-2.33 \pm 0.25^{\mathrm{cd}}$ & $25.67 \pm 0.69^{\mathrm{e}}$ & $2.26 \pm 0.01^{\mathrm{a}}$ \\
$4 \mathrm{~m} / \mathrm{s}$ & $60^{\circ} \mathrm{C}$ & $41.55 \pm 0.72^{\mathrm{bc}}$ & $-1.32 \pm 0.23^{\mathrm{b}}$ & $26.83 \pm 0.91^{\mathrm{cd}}$ & $2.28 \pm 0.13^{\mathrm{a}}$ \\
& $70^{\circ} \mathrm{C}$ & $42.39 \pm 0.75^{\mathrm{b}}$ & $-0.15 \pm 0.10^{\mathrm{a}}$ & $28.08 \pm 0.59^{\mathrm{b}}$ & $2.35 \pm 0.05^{\mathrm{a}}$ \\
\hline
\end{tabular}

${ }^{\mathrm{a}-\mathrm{f}}$ Superscripts with different alphabets in the same column differ significantly $(P<0.05)$.

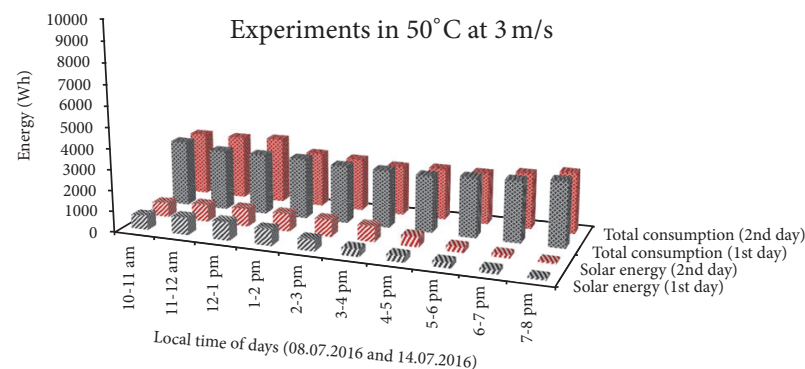

(a)

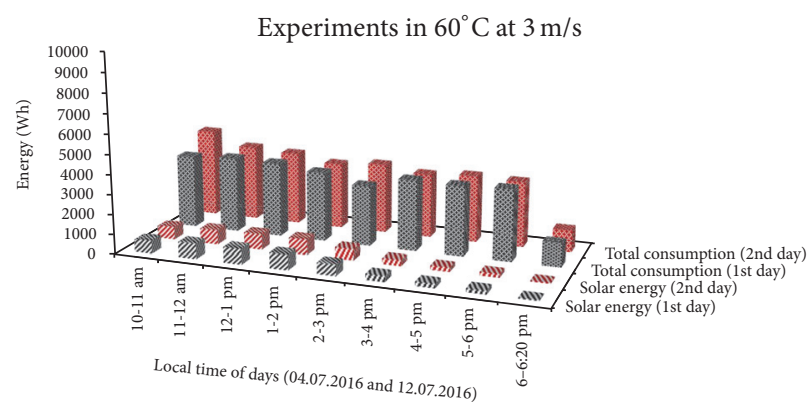

(c)

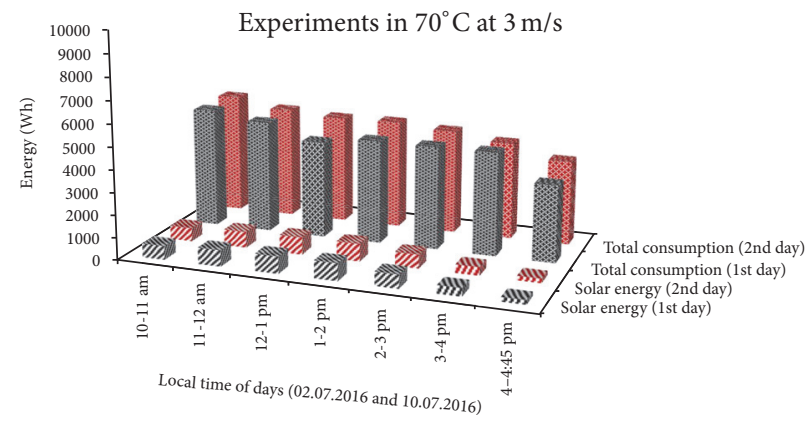

(e)

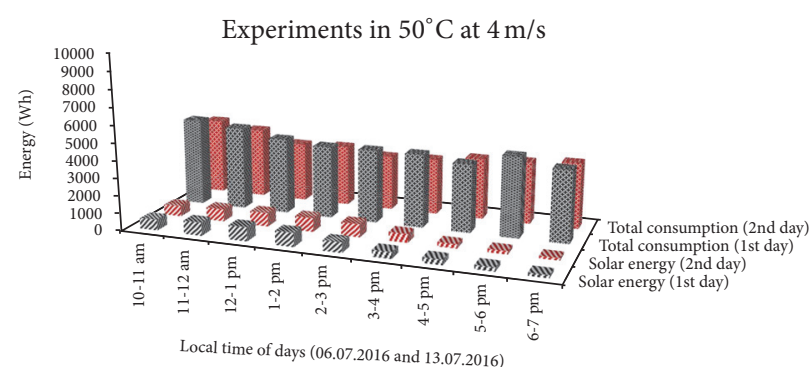

(b)

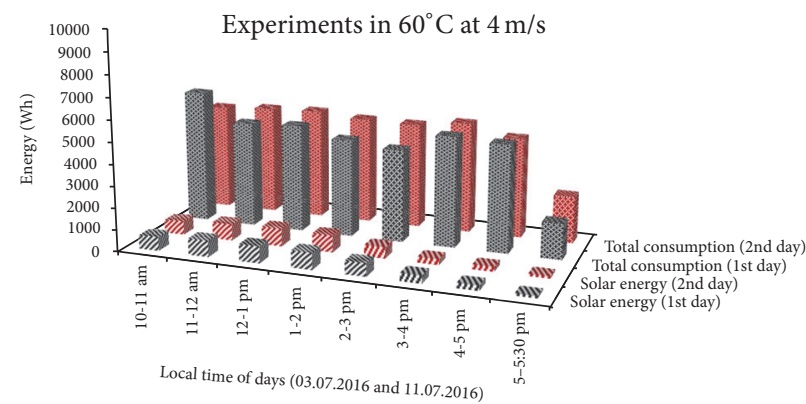

(d)

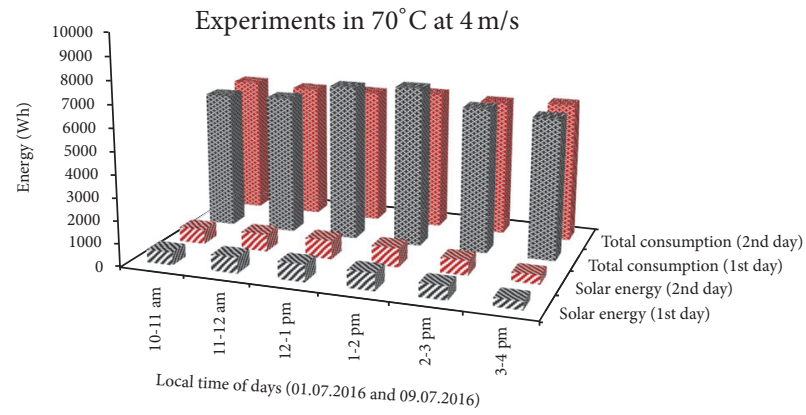

(f)

FIGURE 4: Energy consumption and energy production.

\section{Conclusions}

The industrial drying of green peas with PV energy assistance has been investigated in six different applications here. Dried green peas were analyzed with regard to drying time, color, rehydration, specific energy, and total energy consuming. The obtained results displayed that the increase in the drying air temperature $\left(50^{\circ} \mathrm{C}\right.$ to $\left.70^{\circ} \mathrm{C}\right)$ and air velocity $(3 \mathrm{~m} / \mathrm{s}$ to
$4 \mathrm{~m} / \mathrm{s}$ ) has resulted in decrease in drying duration. Further, experimental results pointed that the specific energy ranges from $7.561 \mathrm{~kW} \mathrm{h/kg}$ to $11.154 \mathrm{~kW} \mathrm{h/kg}$. Ultimately, the color deviation has been exposed in all treatments and also the statistical analysis about rehydration ratio of dried green peas demonstrates that there are no significant differences about the operating conditions such as air temperature and air velocity. Industrial drying with the PV energy assistance is 


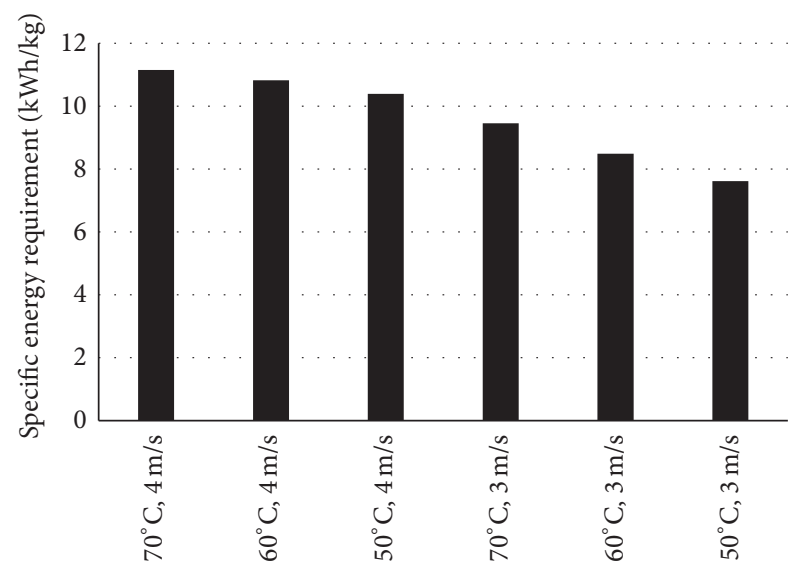

FIGURE 5: Specific energy required for drying of green peas.

a beneficial application for widespread use in agriculture in order to reduce total energy consumption.

\section{Competing Interests}

The authors declare that there is no conflict of interests regarding the publication of this paper.

\section{Acknowledgments}

The authors are grateful to the Research Project Unit of Uludag University for providing the financial support (Project no. OUAP(Z)-2014/20).

\section{References}

[1] M. Zielinska, P. Zapotoczny, O. Alves-Filho, T. M. Eikevik, and W. Blaszczak, "A multi-stage combined heat pump and microwave vacuum drying of green peas," Journal of Food Engineering, vol. 115, no. 3, pp. 347-356, 2013.

[2] FAO, "Food and Agricultural Organization Statistica Database 2016," http://faostat3.fao.org/download/Q/QC/E.

[3] O. İsmail, B. Beyribey, and İ. Doymaz, "Investigation of dehydration and rehydration kinetics of peas subjected to open-air sun drying," Latin American Applied Research, vol. 44, pp. 209216, 2014.

[4] İ. Doymaz and F. Kocayigit, "Drying and rehydration behaviors of convection drying of green peas," Drying Technology, vol. 29, no. 11, pp. 1273-1282, 2011.

[5] S. Sahin, G. Sumnu, and F. Tunaboyu, "Usage of solar-assisted spouted bed drier in drying of pea," Food and Bioproducts Processing, vol. 91, no. 3, pp. 271-278, 2013.

[6] I. Ceylan, M. Kaya, A. E. Gürel, and A. Ergun, "Energy analysis of a new design of a photovoltaic cell-assisted solar dryer," Drying Technology, vol. 31, no. 9, pp. 1077-1082, 2013.

[7] A. Mohajer, O. Nematollahi, M. M. Joybari, S. A. Hashemi, and M. R. Assari, "Experimental investigation of a hybrid solar drier and water heater system," Energy Conversion and Management, vol. 76, pp. 935-944, 2013.

[8] D. B. Jadhav, G. L. Visavale, N. Sutar, U. S. Annapure, and B. N. Thorat, "Studies on Solar cabinet drying of green peas (Pisum sativum)," Drying Technology, vol. 28, no. 5, pp. 600-607, 2010.
[9] A. O. Adelajaa, B. Y. Ogunmolab, and P. O. Akoladec, "Development of a photovoltaic powered forced convection solar dryer," Advanced Materials Research, vol. 62-64, pp. 543-548, 2009.

[10] P. N. Nwosu, V. K. Sharma, O. U. Oparaku et al., "Experimental investigation of a photovoltaic-powered solar cassava dryer," Drying Technology, vol. 30, no. 4, pp. 398-403, 2012.

[11] M. Aktaş, S. Şevik, H. Doğan, and M. Öztürk, "Drying of tomato in a photovoltaic and hhermal solar-powered continuous dryer," Journal of Agricultural Sciences, vol. 18, pp. 287-298, 2012.

[12] M. S. Seveda, "Design of a photovoltaic powered forced convection solar dryer in NEH region of India," International Journal of Renewable Energy Research, vol. 3, no. 4, pp. 906-912, 2013.

[13] J. O. Ojediran and A. O. Raji, “Thin-layer drying characteristics of castor (Ricinus communis) seeds," Journal of Food Processing and Preservation, vol. 35, no. 5, pp. 647-655, 2011.

[14] G. Clemente, N. Sanjuán, J. A. Cárcel, and A. Mulet, "Influence of temperature, air velocity, and ultrasound application on drying kinetics ofc," Drying Technology, vol. 32, no. 1, pp. 6876, 2014.

[15] S. Soponronnarit, A. Pongtornkulpanich, and S. Prachayawarakorn, "Drying characteristics of corn in fluidized bed dryer," Drying Technology, vol. 15, no. 5, pp. 1603-1615, 1997.

[16] W. Jittanit, N. Saeteaw, and A. Charoenchaisri, "Industrial paddy drying and energy saving options," Journal of Stored Products Research, vol. 46, no. 4, pp. 209-213, 2010.

[17] M. Barzegar, D. Zare, and R. L. Stroshine, "An integrated energy and quality approach to optimization of green peas drying in a hot air infrared-assisted vibratory bed dryer," Journal of Food Engineering, vol. 166, pp. 302-315, 2015.

[18] İ. Doymaz and M. Pala, "The thin-layer drying characteristics of corn," Journal of Food Engineering, vol. 60, no. 2, pp. 125-130, 2003.

[19] I. Das, S. K. Das, and S. Bal, "Specific energy and quality aspects of infrared (IR) dried parboiled rice," Journal of Food Engineering, vol. 62, no. 1, pp. 9-14, 2004.

[20] I. Alibas, "Energy consumption and colour characteristics of nettle leaves during microwave, vacuum and convective drying," Biosystems Engineering, vol. 96, no. 4, pp. 495-502, 2007.

[21] A. K. S. Chauhan and A. K. Srivastava, "Optimizing drying conditions for vacuum-assisted microwave drying of green peas (Pisum sativum L.)," Drying Technology, vol. 27, no. 6, pp. 761769, 2009.

[22] L. A. Ramallo and R. H. Mascheroni, "Quality evaluation of pineapple fruit during drying process," Food and Bioproducts Processing, vol. 90, no. 2, pp. 275-283, 2012.

[23] F. Tunaboyu, Usage of solar-spouted bed drier in the drying of parboiled wheat, corn and pea [M.S. thesis], Natural and Applied Sciences of Middle East Technical University, Ankara, Turkey, 2011.

[24] C. Taechapairoj, I. Dhuchakallaya, S. Soponronnarit, S. Wetchacama, and S. Prachayawarakorn, "Superheated steam fluidised bed paddy drying," Journal of Food Engineering, vol. 58, no. 1, pp. 67-73, 2003.

[25] I. Doymaz, "Drying behaviour of green beans," Journal of Food Engineering, vol. 69, no. 2, pp. 161-165, 2005.

[26] C. Rattanamechaiskul, N. Junka, C. Wongs-Aree, S. Prachayawarakorn, and S. Soponronnarit, "Influence of hot air fluidized bed drying on quality changes of purple rice," Drying Technology, vol. 34, no. 12, pp. 1462-1470, 2016. 
[27] İ. Doymaz, "Hot-air drying and rehydration characteristics of red kidney bean seeds," Chemical Engineering Communications, vol. 203, no. 5, pp. 599-608, 2016.

[28] T. M. Afzal, T. Abe, and Y. Hikida, "Energy and quality aspects during combined FIR-convection drying of barley," Journal of Food Engineering, vol. 42, no. 4, pp. 177-182, 1999.

[29] H. Darvishi, M. H. Khoshtaghaza, and S. Minaei, "Effects of fluidized bed drying on the quality of soybean kernels," Journal of the Saudi Society of Agricultural Sciences, vol. 14, no. 2, pp. 134-139, 2015.

[30] D. P. Chielle, D. A. Bertuol, L. Meili, E. H. Tanabe, and G. L. Dotto, "Convective drying of papaya seeds (Carica papaya L.) and optimization of oil extraction," Industrial Crops and Products, vol. 85, pp. 221-228, 2016.

[31] M. E. Adabi, A. Motevali, A. M. Nikbakht, and M. H. Khoshtaghaza, "Investigation of some pretreatments on energy and specific energy consumption drying of black mulberry," Chemical Industry and Chemical Engineering Quarterly, vol. 19, no. 1, pp. 89-105, 2013.

[32] R. A. Chayjan, K. Salari, Q. Abedi, and A. A. Sabziparvar, "Modeling moisture diffusivity, activation energy and specific energy consumption of squash seeds in a semi fluidized and fluidized bed drying," Journal of Food Science and Technology, vol. 50, no. 4, pp. 667-677, 2013.

[33] L. Ben Haj Said, H. Najjaa, M. Neffati, and S. Bellagha, "Color, phenolic and antioxidant characteristic changes of allium roseum leaves during drying," Journal of Food Quality, vol. 36, no. 6, pp. 403-410, 2013.

[34] E. Demiray and Y. Tulek, "Color degradation kinetics of carrot (Daucus carota L.) slices during hot air drying," Journal of Food Processing and Preservation, vol. 39, no. 6, pp. 800-805, 2015.

[35] S. Aral and A. V. Beşe, "Convective drying of hawthorn fruit (Crataegus spp.): effect of experimental parameters on drying kinetics, color, shrinkage, and rehydration capacity," Food Chemistry, vol. 210, pp. 577-584, 2016.

[36] L. Seremet, E. Botez, O.-V. Nistor, D. G. Andronoiu, and G.-D. Mocanu, "Effect of different drying methods on moisture ratio and rehydration of pumpkin slices," Food Chemistry, vol. 195, pp. 104-109, 2016.

[37] H. Fan, Y. Wu, X. Hu, J. Wu, and X. Liao, "Characteristics of thin-layer drying and rehydration of nata de coco," International Journal of Food Science and Technology, vol. 46, no. 7, pp. 14381444, 2011.

[38] E. H. Ohaco, B. Ichiyama, J. E. Lozano, and A. De Michelis, "Rehydration of rosa rubiginosa fruits dried with hot air," Drying Technology, vol. 33, no. 6, pp. 696-703, 2014. 

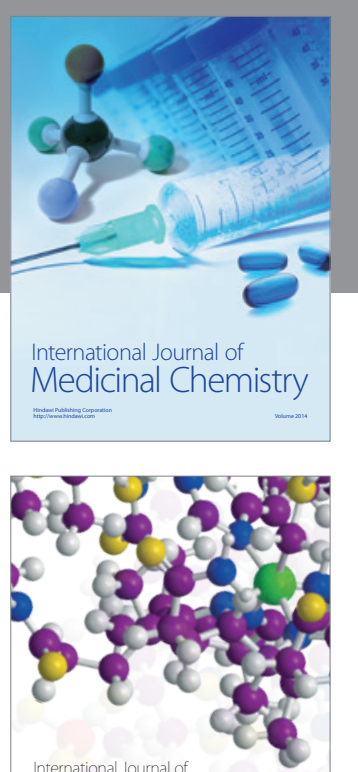

Carbohydrate Chemistry

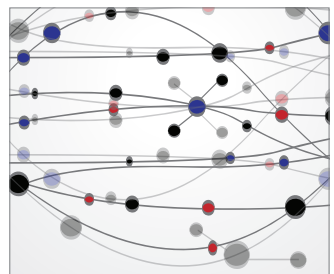

The Scientific World Journal
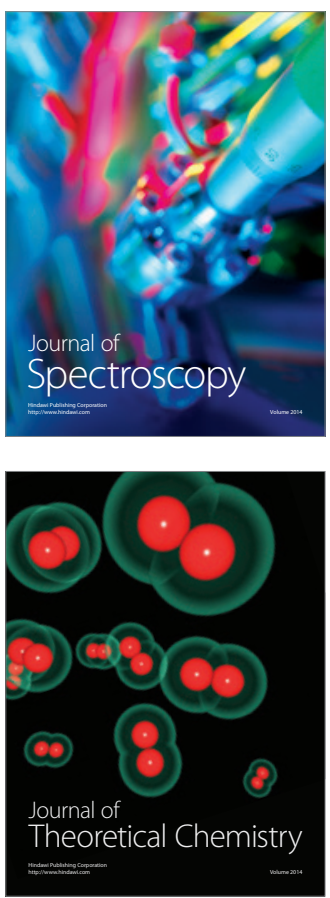
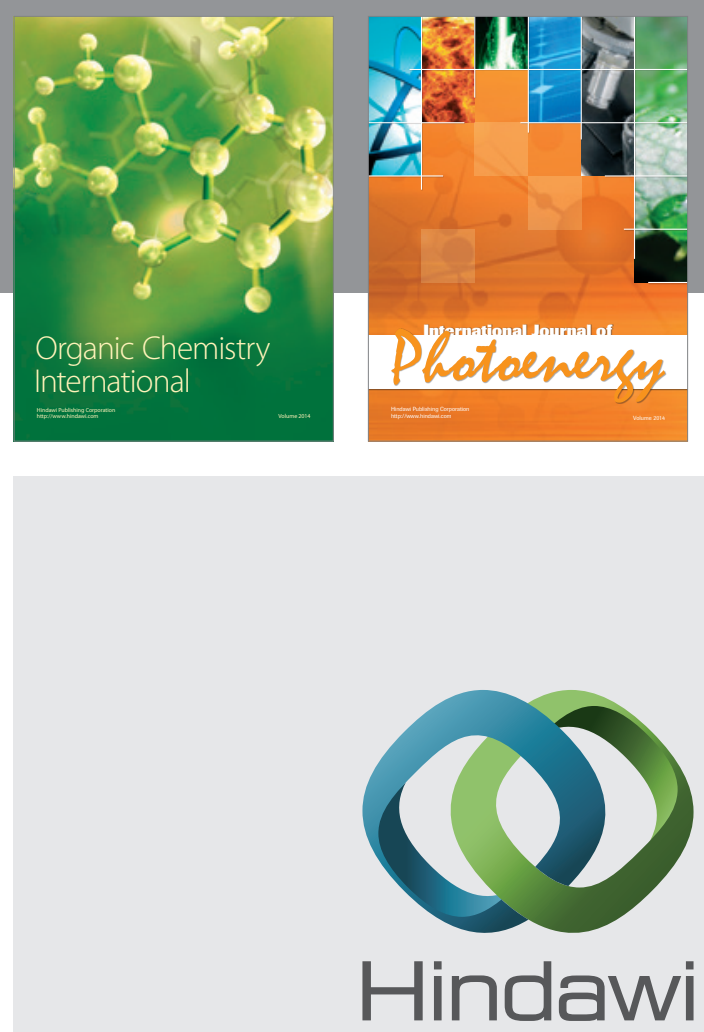

Submit your manuscripts at

http://www.hindawi.com

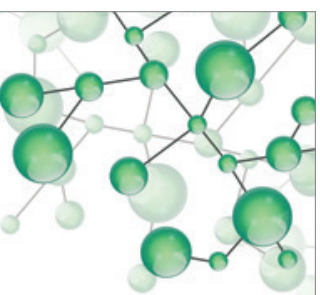

International Journal of

Inorganic Chemistry

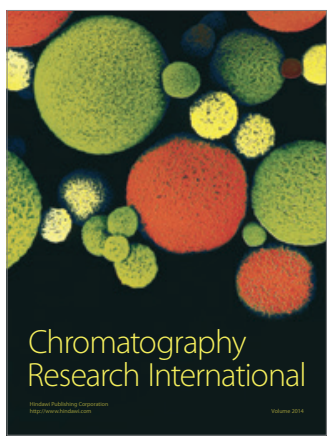

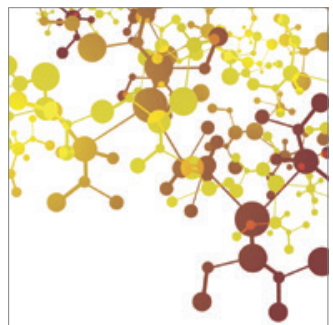

Applied Chemistry
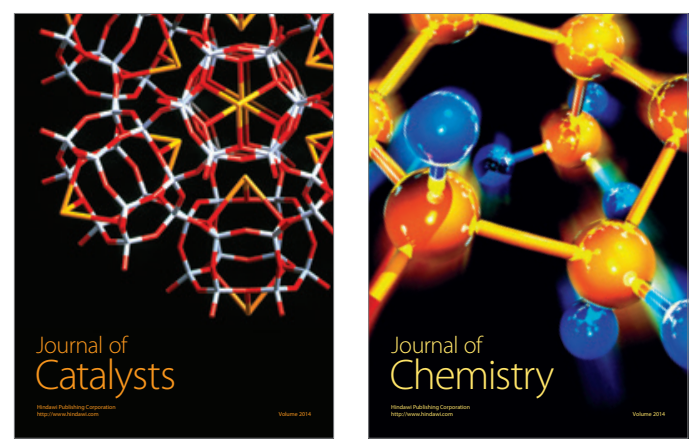
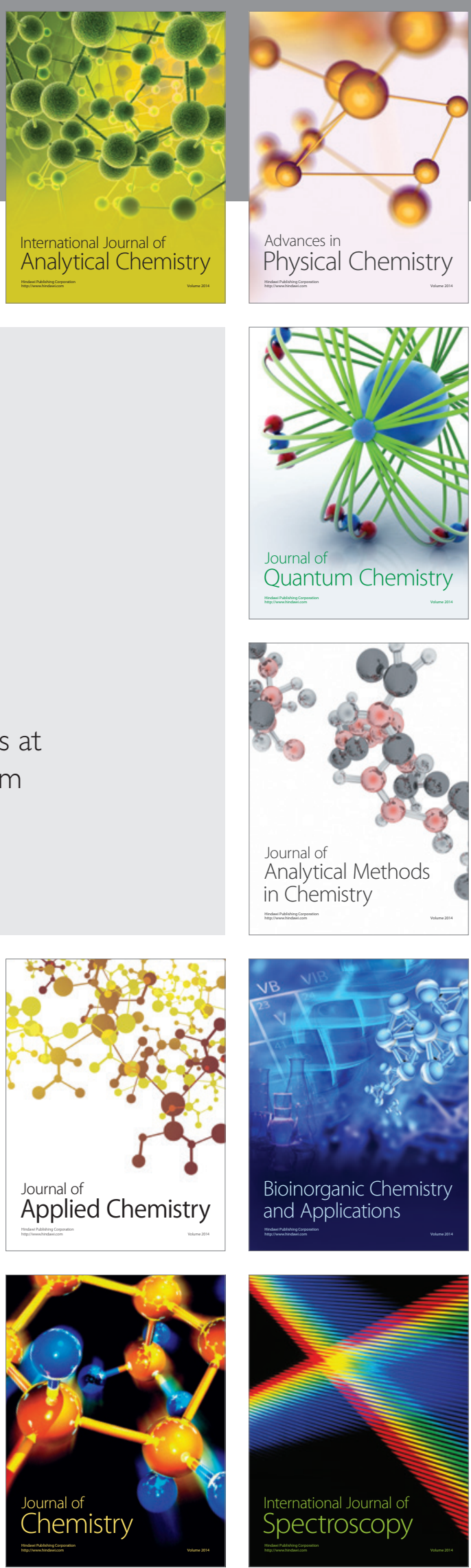